\title{
TRANSPORTZYKLONBKREMATORIA
}

\section{Gerd Korman}

Martin Gilbert. Auschwitz and the Allies. New York: Holt, Rinehart and Winston, 1981. 368 pp. Biographical notes and index. \$15.95.

Lucy S. Dawidowicz. The Holocaust and the Historians. Cambridge, Mass.: Harvard University Press, 1981. xi +187 pp. Notes and index. \$15.00.

Recently a number of books and articles have appeared which should persuade historians to reconsider some of America's activities during World War II. One work, British Intelligence in the Second World War (1981), now in its second volume, reveals how much more British Intelligence knew about German affairs than many officials at the time acknowledged and than historians had imagined. Other studies, based on state and private archives in England, France, Germany, Israel, and the United States, have presented new details and insights to officialdoms in Western democracies, ranging from those in military command to bureaucrats in Vichy, France to public servants in Palestine. Two books written for the general public as much as for the profession, Martin Gilbert's Auschwitz and the Allies and Lucy S. Dawidowicz's The Holocaust and the Historians, provoke important questions about the behavior of Americans when they encountered Germany's "Final Solution," during the war and in the historical records afterwards.

In August 1942 Richard Lichtheim revealed with special clarity the essential secret of that "solution": "We now know that deportation means deathsooner or later," he wrote from his Geneva listening post to colleagues of the Jewish Agency in London. He could not say where the transports stopped and how death came; for to him, then, and for many months to come the last stops remained hidden somewhere in Silesia, surrounded by euphemisms, deceit, and secrecy. Occasionally, the Polish city Oswiecim found its way into the news filtering across German borders, but when it did so it was read as the name of one or more labor camps in Upper Silesia, a region wellknown for its mines and factories. (For the doubters of his insight, the failure to find the last stop of the transports strengthened the belief that actually most Jews were not being killed at all.) Nevertheless, in the face of disbelief, Lichtheim struggled to sustain his convictions and tried to persuade others to 
distinguish what was happening from mass killings of the past, in other wars, or even from recent German mass murders in the lands of the Polish and Russian campaigns. The executions since 1939, he explained, had occurred on the local level, part of an organized system to be sure, but local in character; one assumed, hoped, that there, as in the harshest camps in other wars, the younger and stronger would survive. (Walter Laqueur quotes Lichtheim in Commentary, December 1970, p. 50). But this was different: 'This process of annihilation is going on relentlessly and there is no hope left to save any considerable number." He screamed about four million dead or soon to be dead Jews. ${ }^{1}$

Two years later the secret became public knowledge. Between 1942 and 1944 Auschwitz was the main center of the Final Solution: guards moved hundreds of thousands of Jews directly from the freight trains into the gas chambers from where their bodies were taken to crematoria which sent the remaining ashes into chimneys opening to the skies. Without hyphens, commas, or semicolons, I designate this act TRANSPORTZYKLONBKREMATORIA.

TRANSPORTZYKLONBKREMATORIA remained a thinkable and unstoppable fact until the winter months of 1944-45 because the Allies excluded it from their strategic and tactical military target areas. By late summer of 1944 that exclusion became especially significant, in part because buzz-bomb sites and rebellious Warsaw had become military targets. TRANSPORTZYKLONBKREMATORIA was then a publicly acknowledged condition in East Central Europe. On the ground, in France, American and British soldiers felt victory at hand; Generals Bradley and Patton even saw the high road into Germany for quick victory. General Montgomery disagreed: he wanted the northern route, much closer to the coast, because he wanted to end the war by conquering the Ruhr; the English general also wanted to destroy German forces on the coast, and to get the enemy out of V-1 and V-2 range of English civilians. At the same time Warsaw became a target. In the air war involving English and American units, photographs became available for the entire Auschwitz complex and regional rail network feeding into it. Allied bombers and reconnaissance planes were then raiding I. G. Farben's synthetic fuel plants in Auschwitz as well as other energy sources in East Central Europe. Some of these bombers also flew over the same area on their way to Warsaw where they sought to help the Polish Home Army embattled against German occupiers. On the basis of traditional methods of monitoring and surveillance, TRANSPORTZYKLONBKREMATORIA had become as visible and findable as the allied target areas of buzzbomb launching sites and rebellious Warsaw. But still TRANSPORTZYKLONBKREMATORIA did not become a target area itself. 
Auschwitz and the Allies tries to explain why not. The core of Gilbert's evidence derives from the archives he knows well, those of the ministries and political leaders who made decisions of policy and administration about Jewish affairs during the Second World War. He has supplemented these sources with findings and conclusions published by Walter Laqueur (The Terrible Secret, 1980), Henry Feingold (Politics of Rescue, 1970), David Wyman (Commentary, May 1978), and Bernard Wasserman (Britain and the Jews of Europe, 1979), among others, and with interviews, including one with a survivor from an Auschwitz gas chamber who owes her life to a plane flying over Auschwitz that accidently dropped a bomb near the chamber into which she had been pressed and locked. As official biographer of Winston Churchill, Gilbert has long lived with Whitehall's archival collections from the days of England's wartime ministers assembled in the War Cabinet. He has written about other important subjects of European twentieth-century history, including a number of books especially concerned with Jews and World War II. This prolific English historian has also found fame through his many black-and-white atlases ranging over many parts of the Euro-American world.

Gilbert has organized hundreds of quotations selected from confidential correspondence, often interoffice memos and minutes to the file, in which British ministers and their cadres of civil servants reveal themselves on the subject of Jews during World War II. With the aid of fine maps and photographs, his object is to focus old and new material on the question of when Auschwitz revealed itself. He provides just enough background about events in Europe so that the reader appreciates the information available to the Germans, some of their allies, and some of the Jewish victims, and the information available to specific ministers or civil servants at any given moment, and then presents the official English, American, or Jewish response to that information. While the organization is often loose, even sprawling, Gilbert seeks to achieve dramatic tension by making Auschwitz the focal point of the circulating information. In this book Auschwitz eludes intelligence gatherers working for Jewish agencies in Palestine, Switzerland, England, and the United States. Between 1942 and spring 1944 Auschwitz remains hidden.

What Gilbert's book does not reveal is that British Intelligence in the spring of 1942, had plucked Auschwitz out of the air waves coming from the German Nacht and Nebel. The Government Code and Cypher School decrypted "a daily return of prisoners at Dachau, Buchenwald, Auschwitz, and seven other concentration camps - not all of them," according to F. H. Hinsley and his colleagues in the second volume of British Intelligence in the Second World War (1981), "but a good cross-section." They summarize the results: "The daily returns consisted of a series of unheaded, unexplained columns of 
figures which G.C. and C.S. worked out to mean (a) number of inmates at the start of the previous day, (b) new arrivals, (c) departures by any means, and (d) number at the end of the previous day . . ." G.C. and C.S. read departures by any means "as being accounted for primarily by deaths." The returns revealed that Auschwitz was the largest camp, with 20,000 prisoners, that illness was the main cause of death, but that shootings and hangings also took their fatal toll. ${ }^{2}$

In fact, British Intelligence had broken all the German police ciphers except for the one apparently used by the Gestapo. This meant that unless signals traveled by overland wires or messengers, the British could read, with ups and downs, until late in the war, SS messages and those sent and received by the non-Nazi party uniformed police. Between 1941 and 1943 the British deciphered many reports of authorized mass shootings. Hinsley et al. cite these as illustrative from the summer of 1941: from 18 July-30 August there were seven reports in which the victims were described variously as "Jews," "Jewish plunderers," "Jewish bolshevists," or "Russian soldiers," in "numbers varying from less than a hundred to several thousand ..."; on August 7 the SS Cavalry Brigade reported that it had carried out 7,819 "executions in the Minsk area," and on the same day von dem Bach, commander of police in the central sector, reported that " 30,000 executions had been carried out since the police arrived in Russia"; between 21-23 August, in the Southern Sector, "the shooting of Jews, in groups numbering from 61 to 4,200 was reported on 17 occasions . . . . " 3 In addition, since 1941 the English had also broken many different codes in use by continental railways, in part to sort out troop movements from other kinds of railway traffic. In conjunction with all other information they acquired, I find it hard to believe that by spring and summer of 1942 people in Intelligence and in Whitehall had failed to find the last stops of the deportation trains.

Within Gilbert's sources, Lichtheim and a host of others in Great Britain, Palestine, and America tried, almost always in vain, to gain acceptance and consideration of their pleas. English officialdom at Whitehall, usually with the acquiescence or support of the White House or State Department, managed to give the reasons why persecuted Jews, almost always, could not be treated as extraordinary victims deserving assistance, safe passage, exchange for prisoners of war or material goods, and asylum. The English and American press often called for help. On December 17, 1942, Senza Papa, the allies issued a formal declaration denouncing bestial crimes against Jews. In the United States during 1944 official pressure for action to save Jews mounted. But throughout the two years Whitehall held fast: the horror stories were "familiar stuff" (p. 99). A "disproportionate amount of the time of the [Foreign] Office is wasted on dealing with these Jews" (p. 312). Pressure from 
America reflects the influence of Jewish voters and Henry Morgenthau, Jr. Moreover, according to Gilbert, even on occasion against the explicit wishes of Winston Churchill, Prime Minister of the War Cabinet, Anthony Eden as Foreign Secretary, William Cavendish-Bentick as Chairman of the Joint Intelligence Committee of the Chiefs of Staff, and such other ministers as Oliver Stanley insisted on responding to Jewish children or adults who were escaping or might be able to do so, as if they were "nationals from a country with which we were at war" (p. 103), or as threatening English commitment in Palestine and to the Arabs, or as playing into the hands of Zionist ambitions, or as threatening to exacerbate anti-Semitism in England or the United States.

The final crisis came in the fall of 1944 when Jews in particular appealed for military intervention against TRANSPORTZYKLONBKREMATORIA, when there was still time to protect some 800,000 Jews in Hungary against its impact. Gilbert patiently takes us into the War Cabinet and among some of the officers of the English and American Air Force. He reports concern about the safety of victims facing allied bombs, and about future German claims that air raids and not Germans had killed Jews. He discusses the hopes, confusions, and deceptions surrounding the offer to exchange Jews for trucks. He also identifies some bureaucratic snarls in decision making between the Air Ministry and the Foreign Secretary's Office. But, especially in light of the revelations about British Intelligence, in the end I must conclude that TRANSPORTZYKLONBKREMATORIA was not a fit target for allied public policy and military intervention because the Final Solution had been made into a private affair between Jews and the Germans who occupied Europe.

Much of Gilbert's evidence is similar to what we know about the U.K. (from Wasserman), the U.S. (from Feingold and Wyman), and Vichy, France (from Michael R. Marrus and Robert O. Paxton, Vichy France and the Jews, 1981). Officialdoms there almost always responded to news about Jews through experiences from the interwar period. TRANSPORTZYKLONBKREMATORIA simply did not shatter the potency of that experience and the perceptions and decisions that flowed from it. Within a few minutes of each other some of Gilbert's people had to read and act upon memoranda which acknowledged mass murder and raised the possibility of finding asylum for a handful of refugees. Officials behaved as if the first had no bearing on the second because in their world the two events remained unrelated to each other. It was not that they did not know what TRANSPORTZYKLONBKREMATORIA was, meant, and represented. Whatever it was, it simply made no difference in the locks of past experience.

For that reason, allied responses to Jewish pleading has been misleading. 
The Lichtheims wanted changed behavior because of events in occupied Europe. They pressed for urgency in the corridors where walked the first ministers and their generals who could exploit any and all diplomatic and military opportunities to frighten killers with future punishment and to rescue anyone who could be reached. Beyond such deeds it was understood that circumstances precluded little else, until allied power had come within striking distance of the enemy. When that moment arrived mighty armadas would strike their blows with all possible speed. For that reason, the Lichtheims in 1942 and 1943 agreed with their understanding of the allied slogan: an undivided and undistracted war effort was the quickest way to stop the Final Solution. Who among Jewish leaders would have thought that TRANSPORTZYKLONBKREMATORIA would not be considered fit for the target list, the primary list, the secondary list - for any list?

It is perhaps for that reason that Lucy Dawidowicz's book should not surprise. In recent years she has become a renowned authority on the Holocaust and the Jewish world in Europe it destroyed. Among other publications The Golden Tradition and The War Against the Jews stand as witnesses to her popularity and influence. The non-Jewish historical writing she has examined sounds much the same as the officialdoms Gilbert and others have recently probed. Both Clio's officialdoms and those of political states remained tied to earlier traditions and experiences and responded to events in Germany's Europe in terms of their country's earlier policies and ambitions. Each group of national historians approach World War II from a special perspective and within it usually do not consider the history of the Jews during the occupation as a fit subject for professional concern.

Dawidowicz's historians, in fact, share important premises not only with the ministries active in the work of Gilbert and the scholars who have studied them, but also with ministries busy with Jews in the years between 1945 and 1948. Together they approached Jews in Europe as if the Final Solution made no difference: the earlier interwar period seemingly had provided them with impervious organizing principles and analytical categories. English, Russian, and American diplomats and generals almost always saw Jews as European nationals with a particular religious persuasion or insisted that public policy be blind to Jewish conditions as such. On that basis diplomats and officers in allied military government usually assumed that the experience with TRANSPORTZYKLONBKREMATORIA was comparable to pogroms after 1918: not especially helpful for thinking and planning about Germany, Poland, or Russia and the Jews who happened to live there.

In the 1950s, United States diplomat George Kennan expressed his variants of such approaches and assumptions. He remembered his annoyance with those who tried to obtain special sympathies for Jewish refugees just before 
World War II. He also recalled news about horrendous atrocities after Germany invaded Russia - that is to say, when the European war turned into an Asian conflict within which all belligerents, including Americans, became extraordinarily ferocious. Recently, in a review of The War Against the Jews, Henry Feingold stated the point for many of the historians Ms. Dawidowicz writes about: "students of European history concede that the Jews may have played a disproportionately important role in European history," but "they still hold that it was nevertheless a minor one, all things considered, and so the liquidation of the Jews, terrible as it was, was a relatively minor happening. Genocide is neither unprecedented nor metaphysical. . . . Seen on the large canvas of European history, the Holocaust does not have the importance and the uniqueness it has on the canvas of Jewish history." 4

In this book Ms. Dawidowicz offers her conclusions explaining the different perspectives on the Holocaust which separate her and a relatively small group of heterogeneous historians, almost all Jewish, from the rest of the profession. She does this by first presenting the Holocaust as a distinct phenomenon, and then presenting her impressions of the Holocaust in "the more important works or work characteristic" of the histories available in England, the United States, Germany, Poland, Russia, and those of scholars publishing as historians professionally engaged with Jewish pasts. Her major conclusions are to be found in the Foreword, the Afterword, and scattered throughout the book.

They rest on one important assumption. Professional historians have a "self-imposed mission to construct the past as it was" by striving to "offset individual subjectivity." This standard obliges the historian to engage in "rigorous reading of documents, fair selections of significant data, and honest deliberation." It requires a sensitive distinction between "apologetic" history and "conscientious" history, for that distinction is the prerequisite to "attain the goal of writing objective history." The standard demands locating "the human factor in explaining historical events" so that the historian can "decipher the import of those events." Ms. Dawidowicz knows what sort of work will flow from such a standard: "history is at bottom an account of what men did and achieved, and the historian's task is to untangle that meshwork of human character, behavior, and motive whose intertwining creates the very material of history." She identifies the one historian who for the subject of the book lived up to that professional standard. Karl Dietrich Bracher's The German Dictatorship (1969) "combined scrupulous objectivity, moral judgment, and a passionate commitment to the democratic ethos. . . . It is a work of unparalleled distinction in all the historical literature on the Third Reich produced in any language." It also agrees with her. It "recognized from the start the Nazis assigned primacy of place, in doctrine and in action, 
to make hatred of the Jews with all its tragic consequences, a cardinal feature of the state's policy" (pp. 65-67).

On the basis of such a standard Ms. Dawidowicz concludes that the encounter with the Holocaust has led to professional failure on an international scale. Within the framework of "national traditions or political situations," a general "lack of interest in the fate of Jews," was especially responsible for this particular lapse from professional standards. She makes her case most effectively when examining the publications of historians in the service of National Socialism and Communism. Here the standard does not exist. Understanding party policies explains Orwellian history. In each instance, but with special detail for Poland and Russia since 1945, Ms. Dawidowicz reveals party needs against the background of historical and current events. One result in the 1950s, before Stalin's death, was to make armed resistance "a historical theme" and "given pride of place," an approach that reflected the prescribed approach in Soviet and Polish historiography. Another consequence muted or eliminated anti-Semitism among Poles and stressed instead their wartime friendliness toward Jews. Then, between 1953 and 1956 the line changed or loosened. Accounts about the war and Jews followed suit, and until the mid-sixties moved closer to nonideological history. After 1967 Poland and Russian party needs changed again and Dawidowicz traces them to the logical end where "History Done, Redone, and Undone" uses evidence from the Stalinist era and turns Zionists into organizers of the Holocaust! (p. 78).

Her discussion of historians working in England, the United States, and Germany is not so useful. To be sure, it is helpful to have some additional evidence for conclusions about American historians available to the profession since at least 1970. It is also convenient to have an informative summary of German monographs on historians in Germany during the Nazi period. But these benefits do not compensate for the general weakness inherent in this part of her book. Without some sort of systematic approach to the historians' changing, many-sided literature since World War II, it is hard if not impossible to present the texture and subtlety of the many books and articles published in English and German. Her standard, and the way she uses it in selecting works for discussion and analysis, just won't do. The point is not that her general conclusions are wrong; the approach and the method she uses simply do not warrant them.

There is another yet deeper problem with this part of the book. Especially in passages involving Jewish scholars, historiography, and history Ms. Dawidowicz is too engaged, too devoted to her passions to be entirely trusted with the method she employs. Correctly, she calls attention to a select group of historians who as Jews shared a personal experience with National 
Socialism, which in the United States made them different from their colleagues in the profession: George Mosse and Fritz Stern are among them, and Ms. Dawidowicz applauds them. Peter Gay is another, a prolific and influential student of European society and culture who has contributed significantly to the literature about Germans and Jews. A lonely footnote mentioning him as one of the two senior editors of the Columbia History of the World won't do, even though Ms. Dawidowicz's criticisms of the work are valid enough. Since 1972, when that History was published, Gay has written some of the most powerful passages available denouncing trivializers of the Holocaust and those who deny its particular German and Jewish characteristics.

Yehuda Bauer is another example, perhaps an even more glaring one, of the weaknesses inherent in Ms. Dawidowicz's approach. An Israeli scholar who has devoted his entire career to the study of the Holocaust, he has an international reputation of distinction. Some American historians may be familiar with his studies of the American Jews and the Holocaust. He deserves more than a footnote to his "popular pamphlet," even if its title, They Chose Life: Jewish Resistance in the Holocaust, can be taken as "an offense against the murdered Jews in its implication that those who did not engage in armed resistance to the Germans chose death over life" (p. 178). But there is more here than meets the eye. In her important discussion of Jewish historians and the Holocaust are embedded all sorts of ideological currents and such problems as continuities and discontinuities in Jewish history. For Ms. Dawidowicz the state of Israel, in relation to the world the Holocaust destroyed, is at or near the heart of such problems. Ms. Dawidowicz believes the "destruction of the European Jews during the Second World War eclipsed all previous disasters in Jewish history and may have imperiled the future of the Jewish people . . ." (p. 141). She also argues that Israel as a political state was "legitimated as a recompense for the murder of the European Jews," and as a community "is producing a radically different Jewish culture from that of European Jewry." It is not yet evident, she says about Bauer's society, "whether Israel can develop the creative cultural energy that will succeed" in doing what her Jewry in Europe had done: "binding Jews of the world together, while conserving the traditions of the past and evolving new ones" (p. 14). For his part, Bauer lives within ideological tradition not particularly receptive to such judgments. But obviously they cannot so interfere with the scholarship of professional historians à la Bracher.

For American historians these features of combat are not so important as are other aspects of the books reviewed here. The Holocaust and the Historians shows us the international variations with which colleagues have obscured our vision toward the recent past. If Ms. Dawidowicz is correct, on the subject of the Holocaust at least, the difference between colleagues in 
America and those abroad may be much smaller than we like to admit. In that connection the similarity between Clio's officialdom and those of political states between 1939 and 1948 may deserve special scrutiny, if only because a study of that subject may probe deeply into the nature of American nationalism and professionalism in those important years of the republic's history.

As a phenomenon in Euro-American history, the Holocaust contains some other important subjects for American historians. After 1941 the zone of TRANSPORTZYKLONBKREMATORIA was as much a part of the American war as it was a part of the war being waged by European allies. Yet that zone did not become part of the military's target area. Revelations from England's intelligence archives about German behavior in occupied Europe prompt general questions about the circulation of intelligence information between English and American officials, and, in connection with other evidence, focus once again upon Euro-America in the shaping of anti-Jewish policies.

Finally, there is the controversial subject to which Ms. Dawidowicz also calls attention, the struggle against prison, forced labor, and slavery. Since the war itself, attention has remained on acts of armed resistance and their relative importance in understanding Jews and the Nazi regime that ruled them. Early on, academics and publicists in this country offered points of comparison and analogy with other circumstances, in part because "resistance" had been charged with ideological purposes and was becoming an object of social scientific investigation concerned with anomy, autonomy, or alienation. This entire discussion is itself fit for the American historian's scrutiny.

In other words, the Holocaust and its preconditions are an important part of Euro-American history. The profession will come around to acknowledging that fact in its departmental offerings and research ventures. After all, just last year a special committee of the Organization of American Historians certified that the Holocaust was not a figment of the Jewish imagination.

Professor Korman, New York State School of Industrial and Labor Relations, Cornell University, is the author of many articles on American historians and the Holocaust.

1. Richard Lichtheim, quoted by Walter Laqueur, "Jewish Denial and the Holocaust," Commentary 66 (December 1979): 50.

2. F. H. Hinsley et al., British Intelligence in the Second World War, vol. 2 (Cambridge, England: Cambridge University Press, 1981), pp. 673-74.

3. Ibid., vol. 1 (1979), pp. 357-58.

4. Henry Feingold, Jewish Social Studies 38 (Winter 1976): 83. 